\title{
Management of Academic Services in Building Student Satisfaction in Private Islamic Religious College: A Descriptive Qualitative Analysis Study at STAI Al Musaddadiyah, STAI Darul Arqam, and STAI Persis in Garut Regency
}

\author{
Yufi Mohammad Nasrullah, Tb. Abin Syamsudin, Sofyan Sauri, Waska Warta \\ Nusantara Islamic University, Bandung, West Java, Indonesia \\ Email: yufimohammad@uniga.ac.id, abinsyamsuddin@upi.edu, uyunsupyan@uninus.ac.id, \\ waskawarta@gmail.com
}

\begin{tabular}{l} 
ARTICLE INFO \\
\hline Received: 08-09-2022 \\
Revision: 13-09-2022 \\
Received : 00-00-2022 \\
\hline Keywords: \\
Management; \\
academic services; \\
student satisfaction
\end{tabular}

ABSTRACT

This research is motivated by student dissatisfaction with academic services, who are often dissatisfied with the academic services provided, such as facilities and staff performance that are not in line with the expectations of students as customers. This study aims to provide an overview of academic service management in building student satisfaction which includes: (1) Planning; (2) Implementation; (3) Evaluation; (4) Results and achievements; (5) Supporting factors; (6) Inhibiting factors; (7) Hope; (8) Solution. This research method used a descriptive method with a qualitative approach and case study design, in the process by observation, interviews and documentation. The management theory appropriate for the service is the modern management theory. Terry. G. clarifies these management functions in four parts, namely as follows: planning (Planning), organizing (Organizing), actuating, and controlling (Controlling). The results of the study show that there was a different understanding and implementations where STAI Al Musaddadiyah established the process of academic services in the expanding student's satisfaction which was supported by an academic service information system, STAI Darul Arqam was supported by an integrated program from the centre, a program of learning supports STAI Persis. All components, policymakers, authorities, and interested parties were required to support the realization of good quality academic services. The achievement of quality academic services would build creative, innovative, productive resources and had the value of independence to build self-potential in creating a quality culture in private Islamic religious colleges.

\section{Introduction}

generation for the sustainability of the

Education is a conscious and systematic effort in building the potential of students. Education is also an effort of the community and nation to prepare the next community's life and the nation for a better future (Sauri, 2013).

Universities must take anticipatory steps to face increasingly competitive

\footnotetext{
How To Cite: Yufi Mohammad Nasrullah, Tb. Abin Syamsudin, Sofyan Sauri, Waska Warta (2022) Management of Academic Services in Building Student Satisfaction in Private Islamic Religious College: A Descriptive Qualitative Analysis Study at STAI Al Musaddadiyah, STAI Darul Arqam, And Stai Persis in Garut Regency. Journal of Social Science, 3(1). https://doi.org/10.46799/jss.v3i1.294

E-Issn: 2721-5202

Published By: Ridwan Institut
} 
competition and are responsible for exploring and improving all aspects of the services they have because a service owned by a particular institution will illustrate the quality of the institution (Sallis, 2006). An institution can be said to be good, but on the other hand, if the service provided by an institution is terrible, then the institution will be said to be wrong (Hutasoit, 2011).

Delegation of authority to oversee educational and non-educational study programs. As educational service institutions, STAI Al Musaddadiyah, STAI Darul Arqom, and STAI Persis, there is a delegation of authority to manage the fulfilment of quality assurance for students. The main thing that directly intersects with students is guaranteeing the quality of academic services. So based on the decentralization, STAI Al Musaddadiyah, STAI Darul Arqom, and STAI Persis are obliged to fulfil quality assurance.

The teaching and learning process is part of academic activities in higher education, of course, can affect the running of the educational process. Along with the development of technology, universities are required to improve their professionalism in academic and non-academic fields to facilitate the speed and accuracy of service (Lupiyoadi \& Hamdani, 2006). One of them is academic services. Many things cause difficulties in performing these services. One of them is the unavailability of data and the difficulty of stakeholders' accessibility to databases and information related to academics. Integrating Information Technology to improve the quality of the processes, outputs and outcomes of learning carried out in higher education is an absolute thing (Sufiyyah, 2011). It must be done to ensure the quality of higher education in the era of information technology (Tjiptono \& Diana, 2003).

The management theory that is very much in line with service is the modern management theory (Barata, 2003). Terry (201:79), in his book "Principles of Management" clarifies the management functions in four parts, namely as follows: planning, organizing, actuating, controlling. According to him, people make plans or patterns about future activities with integrity and predetermination. This requires predicting, visualising, and looking ahead based on specific goals (Siagian, 2005). In short, there is a need for "planning or planning" planning is a fundamental function of management.

\section{Academic Service Quality}

The definition of academic services in the learning curriculum, according to (Rosita et al., 2011:3), is a systematic effort of education to facilitate students mastering curriculum content through the learning process so that they can achieve the competency standards applied.

Academic service quality compares the academic service perceived by customers or stakeholders with the academic service quality expected by customers or stakeholders (Arief, 2007) (Pakpahan, 2004:47). If the perceived quality of academic services equals or exceeds the expected service quality, the service is of high quality.

According to Philip Kotler in (Supranto 2011: 231), there are five elements in service quality which can be detailed as follows:

1) Trust or reliability: the ability to carry out the promised service appropriately and reliably.

2) Responsiveness: the ability to help customers and provide services quickly or responsively.

3) Assurance: Knowledge and courtesy of the administrative staff and their ability to generate trust and confidence (Djanali \& Mutu, 2003).

4) Empathy: a condition for caring, giving personal attention to customers.

5) Tangibles: the appearance of physical facilities, equipment, personnel and communication media. 


\section{Student Satisfaction}

Satisfaction is individual. Each individual has a different level of satisfaction according to the prevailing value system (Rivai, 2004). The higher the assessment of the activities that are felt to be under the individual's wishes, the higher the satisfaction with these activities. Thus, satisfaction is an evaluation that describes a person's feeling of being happy or not happy in his activities.

Customer satisfaction is the level of feeling in which a person states the results of comparing the performance of the product or service received and expected (Kotler, 2000). Someone with a high level of satisfaction indicates a positive attitude. On the other hand, someone dissatisfied with his job indicates a negative attitude (Marknesis, 2009).

Furthermore, job satisfaction includes the following indicators: 1) The work itself, 2) Job compatibility with personality, 3) Wages and promotions, 4) Attitudes of coworkers and superiors, and 5) Conditions of the work environment.

Meanwhile, if further reviewed, the achievement of customer satisfaction through service quality can be improved by several approaches (Abbas, 2009), there are 1) Minimizing the gaps between management and customers. Likewise, research with the observation method for company employees about implementing services. 2) The company must build a shared commitment to creating a vision for service process improvement. 3) Provide opportunities for customers to submit complaints. Establish a system of suggestions and criticisms, for example, with a toll-free hotline. 4) Develop and implement accountable, proactive, and marketing partnerships according to the marketing situation.

\section{Method}

This type of research is qualitative research (Moleong, 2021), which aims to examine the optimization of academic services at STAI Al Musaddadiyah, STAI Darul
Arqam, STAI Persis, Garut Regency. Research data sources were obtained through direct interviews with the Head of STAI and the Head of the Academic Section. The focus in this study is under the research objective, namely academic service management in building student satisfaction. The time of the implementation of the research is from August 2021 to December 2021.

The techniques used in data collection include observation, interviews and documentation (Sugiyono, 2013). The discussion used in this research is structured. The analytical process used to analyze the data in this research is descriptive qualitative. The data analyzed in the study began with face-to-face interviews because this media became the most effective choice to obtain more precise information. This is because if there is a misunderstanding, the researcher can reconfirm the statement from the informant.

During the interview process, interviews were recorded using a voice recorder application. The interview process lasted approximately 30 minutes. The interview instrument used is guided by management theory. The device is related to aspects of Academic Service Management in Building Student Satisfaction in STAI Al Musaddadiyah, STAI Darul Arqam, and STAI Persis in Garut Regency. This interview instrument was used so that the questions asked focused on academic service management. Furthermore, after the data was collected through interview transcripts, it was analyzed using interactive techniques. This technique will analyze the data in several stages, namely reducing the data, presenting the data, verifying the data, and finally presenting it as a conclusion (Miles \& Hubberman, 1994).

\section{Results And Discussion}

The author's interview results with several sources, including Mr Luqman. M.Sos said that: 
Management of Academic Services in Building Student Satisfaction in Private Islamic Religious College: A Descriptive Qualitative Analysis Study at STAI Al Musaddadiyah, STAI Darul Arqam,

And Stai Persis in Garut Regency

The planning stage in achieving the goals that STAI Siliwangi will achieve is to build a college in the era of globalization by using Quality Management Planning. It is done with several stages, namely: 1) Policies Taken, 2) Academic and Student Affairs Program, 3) Military Program, Assistance Program, 4) Assistance Program (interview with Mr Luqman. Wk Chairman! STAIDA Garut, August 15, 2021).

In line with the statement of Mr Luqman, Mr Ceceng Salamuddin, Permanent Lecturer of STAI Musadaddiyah Garut, said:

The implementation of Quality Management STAI Musadaddiyah Garut is a college that cannot maintain its quality will lose in various competitions. In college management, the main goal is to improve the quality of sustainable productivity because the final stage of the quality of college performance is primarily determined by the quality of collective performance of each member of the academic community, including lecturers. Thus, the management of STAI development must have the primary goal, namely the increase in the quality of productivity through improving work efficiency as educators, researchers in community service or, more precisely, in service to the community. Continuous improvement of quality is the duty and responsibility of all parties following the concept of integrated quality control.

Mr Agus Muharram as a lecturer of STAI Persis, said that;

Academic quality standards at STAI have not been uniform. Such as the standard of awarding student exam results. Particular lecturers are very loose in giving value to their students. While in reputable and advanced universities, usually, the grades are given objectively and tend to be below. As a result, cpns admissions are generally widely accepted, especially in high-value areas, even with low competence. Thus, our bureaucracy is filled with less competent people.

STAI leadership also consistently implements A2K policies (improved access, accountability, and quality). The head of the college opens wide the opportunity for the community to study on the campus he leads. Lecturers also provide excellent service to students starting to learn in college, structured guidance, thesis guidance, etc. Do not let some lecturers are very difficult to find on campus. The learning process must be controlled together so that our graduates will be qualified, competitive, and missed by the community (Interview with $\mathrm{Mr}$ Agus Muhaarram as Lecturer of STAI Persis).

From the interviews with the vicechairpersons, the author of STAI Garut Quality Management covers management, military, facilities and infrastructure, and academic culture. Regarding leadership, STAI does not yet have standard operating procedures (SOPs) and perfect job descriptions and the campus governance system between campuses. Now the STAI campus off-campus has not been integrated. Human resources development, both lecturers and administrators personnel, is not well planned. The number of qualified technicians and workers is still limited. Recruitment of teaching staff has not been following the needs of the study program, especially in terms of quantity. The English language skills of lecturers, students and administrative personnel also need to be improved. The service of proposing the career improvement of lecturers and administrative personnel, technicians, labourers, and librarians have not been optimal. Therefore, it is caused by several factors, among others:

a) Academic service management planning in building student satisfaction

The performance of the academic department in educational service planning has been well programmed, constantly considering all the needs and main tasks of each staff and the distribution of which has no problems due 
to good coordination. So that with good planning will improve the quality of academic services and create student satisfaction.

b) Implementation of academic service management in building student satisfaction

The implementation of academic services is carried out by considering the conditions. Like during a pandemic, learning activities are carried out with blended learning. This is adjusted to the state of student readiness. Academic services are provided to students by always paying attention to aspects of student needs.

c) Evaluation of academic service management in building student satisfaction

The assessment of educational service management is carried out through the distribution of questionnaires or questionnaires filled out by students as feedback on the learning provided by the lecturer for one semester. Evaluation is also carried out by involving students in evaluations to feel academic activities and provide feedback on every service provided.

d) Results and achievements of academic service management in building student satisfaction

Results and achievements in academic service management include students getting their rights in undergoing the tri dharma of higher education. Besides that, the public acceptance of graduates is positive. Besides that, the response of graduate users who always give good grades adds to the institution's excellent image. The absorption of graduation in the world of work is also one of the indicators of achievement in academic service management.

e) Factors supporting academic service management in building student satisfaction
The carrying capacity of the institution in academic services is that the institution under study is a private institution under the auspices of a foundation together with other educational units so that they support each other in addition to having support because they are born from community organizations (jamiyah) according to the basis of their work.

f) Inhibiting factors of academic service management in building student satisfaction

Inhibiting factors in providing academic services include limited infrastructure, limited human resources and the use of technology that has not been maximized, so adjustments are needed, especially during the pandemic.

g) Academic service management solutions in building student satisfaction

The solution in academic service management to build student satisfaction is to put forward more Islamic values. The three institutions studied feel that they have more value because religious values are the hallmark of each student. This graduate is a campus branding power for the community. As a campus with links with one of the jamiyah community organizations, this is a source of strength and input for incoming students.

\section{Conclusion}

Based on the purpose of the study, policymakers, authorities, and interested parties were required to support the realization of good quality academic services. The achievement of quality educational services would build creative, innovative, productive resources and had the value of independence to make self-potential in creating a quality culture in private Islamic religious colleges. Moreover, there are several characteristics to achieve sound management of academic services in building student satisfaction. 
Management of Academic Services in Building Student Satisfaction in Private Islamic Religious College: A Descriptive Qualitative Analysis Study at STAI Al Musaddadiyah, STAI Darul Arqam, And Stai Persis in Garut Regency

\section{References}

Abbas, Syarisay. (2009). Manajemen Pendidikan Tinggi Edisi Revisi. Jakarta: Kencana.

Arief, Muhtosim. (2007). Pemasaran jasa dan kualitas pelayanan. Malang: Bayumedia Publishing.

Barata, Atep Adya. (2003). Dasar-dasar pelayanan prima. Elex Media Komputindo. Google Scholar

Djanali, Supeno, \& Mutu, Pedoman Penjaminan. (2003). Pendidikan Tinggi Bidang Akademik. Jakarta: Departemen Pendidikan Nasional Direktorat Jenderal Pendidikan Tinggi. Google Scholar

Hutasoit, C. S. (2011). Pelayanan Publik Teori dan Aplikasi. Jakarta: Magna Script Publishing.

Kotler, K. (2000). Marketing Management the Millennium Edition. New Jersey: Prentice Hall.

Lupiyoadi, Rambat, \& Hamdani, Ahmad. (2006). Manajemen pemasaran jasa.

Marknesis, Tim. (2009). Customer Satisfaction and Beyond. Yogyakarta: Marknesis.

Miles, N. B. \& Huberman, A. M. (1994). Qualitative data analysis: An expand sourcebook. London: Sage Publication. Google Scholar

Moleong, Lexy J. (2021). Metodologi penelitian kualitatif. PT Remaja Rosdakarya. Google Scholar

Sallis, Edward. (2006). Total Quality Management in Education: Manajemen Mutu Pendidikan, terj. Ahmad Ali Riyadi, et. Al., Cetakan Ke IV. Yogyakarta: IRCISOD.

Sauri, S. (2013). Implementasi Pendidikan Karakter Melalui Kegiatan Kemahasiswaan. Bandung: Sofyan. Google Scholar

Siagian, Sondang P. (2005). Fungsi-fungsi manajerial. Google Scholar

Sufiyyah, Arrafiatus. (2011). Pengaruh Kualitas Layanan Akademik dan Birokrasi terhadap Kepuasan Mahasiswa. Jurnal Ilmiah Aset, 13(2), 85-93. Google Scholar

Sugiyono, Dr. (2013). Metode penelitian pendidikan pendekatan kuantitatif, kualitatif dan R\&D. Google Scholar

Tjiptono, Fandy, \& Diana, Anastasia. (2003). TQM: Total Quality Management. Andi Offset. Yogyakarta.

\section{Copyright holder :}

Yufi Mohammad Nasrullah, Tb. Abin Syamsudin, Sofyan Sauri, Waska Warta (2022)

First publication right :

Journal of Social Science

This article is licensed under:

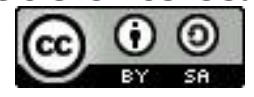

